\title{
Comparison of direct-seeded, bareroot, and various tray seedling densities on growth dynamics and yield of long-day onion
}

\author{
Daniel I. LESKOVAR ${ }^{\mathrm{a} *}$, Miguel CANTAMUTTO ${ }^{\mathrm{b}}$, Pablo MARINANGELLI $^{\mathrm{b}}$, Eloisa GAIDO ${ }^{\mathrm{c}}$ \\ ${ }^{\mathrm{a}}$ Texas A\&M University, TAES, Uvalde, Texas 78801, USA \\ ${ }^{\mathrm{b}}$ Universidad Nacional del Sur, Departamento de Agronomía, Bahia Blanca, Argentina \\ ${ }^{\mathrm{c}}$ Municipalidad de Bahía Blanca-Universidad Nacional del Sur, Argentina
}

(Received 10 January 2003; accepted 1st December 2003)

\begin{abstract}
Root, bulb and shoot growth of transplanted onions produced from seedlings on 228-cell flats were determined. Treatments were one (TC1), two (TC2) or three (TC3) seedlings/cell, and single plants separated at transplanting from those grown with two (TC2-1) or three (TC3-1) seedlings/cell. Controls were direct seeding (DS) and bareroot transplants (BR). Transplants were established with the following inrow spacings: $5 \mathrm{~cm}$ (BR, TC1, TC2-1 and TC3-1), $10 \mathrm{~cm}$ (TC2) and $15 \mathrm{~cm}$ (TC3). During early to mid-development root number and root dry weight were higher for TC1 as compared with BR. Transplant leaf mass peaked between 64 and 80 days after transplanting (DAT). Initially, DS had a rapid bulbing rate, while transplants exhibited a faster rate 60 DAT. Before final maturity, TC1 had a higher bulb size than DS and TC3. Total yields were similar, but yields by size class differed significantly between treatments. DS and TC 3 had an increase in the small bulb size (35-50 mm diameter). All containerized transplants, except for TC3, had an increase in the large bulb size (60-70 mm). TC1 had 36\% of the total marketable yield in the jumbo size $(>70 \mathrm{~mm}$ ) compared with $16 \%$ for direct seeding and $24 \%$ for bareroot transplants.
\end{abstract}

\section{Allium cepa / direct seeding / onion plugs / bareroot transplants / onion shape}

Résumé - Comparaison entre le semis direct, la transplantation à racine nue et diverses densités de plants en godets dans la dynamique du développement et la production d'oignon de jour long. Développement d'oignon transplanté à densité augmentée. Le développement de la racine, du bulbe et du tige d'oignon transplanté obtenu à partir de plants en godets de 228 compartiments a été étudié. Les traitements ont été un (TC1), deux (TC2), ou trois (TC3) plants/compartiment, et une plante séparée dans la transplantation de celles développées avec deux (TC2-1) ou trois (TC3-1) plants/compartiment. Les contrôles ont été : semis direct (DC) et transplantation à racine nue (BR). Les plantes transplantées ont été disposées en rangée avec les distances suivantes : $5 \mathrm{~cm}$ (BR, TC1, TC2-1, TC3-1), $10 \mathrm{~cm}$ (TC2), et $15 \mathrm{~cm}$ (TC3). Pendant le premier et le mi-développement le nombre de racines et le poids sec de racines a été supérieur pour TC1 comparé avec BR. La masse de feuilles des plantes transplantées s'est desséchée dans les 64 et les 80 jours après la transplantation (DAT). Initialement, DS a eu un taux de formation de bulbe rapide, tandis que les plantes transplantées ont montré un taux plus rapide 60 DAT. Avant la maturité finale, TC1 a eu une taille des bulbes plus grande que DS et TC3. Les productions totales ont été semblables, mais la production en classes de taille a différé de manière significative entre les traitements. DS et TC3 ont eu une augmentation dans la taille des bulbes petits (35-50 $\mathrm{mm}$ de diamètre). Tous les plants en godet, excepté TC3, ont eu une augmentation significative dans la taille des bulbes grands $(60-70 \mathrm{~mm})$. TC1 a eu $36 \%$ de la production totale commercialisable avec la taille jumbo $(>70 \mathrm{~mm})$ par rapport à $16 \%$ pour le semis direct et à $24 \%$ pour la transplantation à racine nue.

Allium cepa / semis direct / calibres de l'oignon / transplantation à racine nue / forme de l'oignon

\section{INTRODUCTION}

In south Buenos Aires, Argentina, long-day onions (Allium сера L. cv. Valcatorce INTA Valenciana type) are grown in about 10000 ha [4]. Valcatorce is also grown in Chile and Uruguay, with significant exports to Brazil, the US and European countries. Onions are generally established by direct seeding; however, extreme environmental conditions and soil-borne diseases often reduce plant survival and fields are commonly reseeded, a practice that delays maturity with the potential decrease in yield and overall quality. To avoid or reduce those risks, growers generally use field-grown bareroot transplants at plant populations that range from 300000 to $500000 \mathrm{pl} \mathrm{ha}^{-1}$ $[1,5]$. Recently, there has been a marked interest in greenhouse-grown cell plants, a relatively new activity for onions in the US and Argentina. High plant stands, more root growth and superior bulb quality were produced with 8-10-week-old containerized transplants grown in 4.0 to $7.1 \mathrm{~cm}^{3}$ cell volume, or with 10-12-week-old transplants grown in larger cell volumes [9]. Transplants generally require less irrigation, herbicide control and pesticide inputs compared with direct seeding. However, due to the high plant population required for onions,

* Corresponding author: d-leskovar@tamu.edu 
containerized transplants are more costly. Evaluation of alternative methods to offset the high initial cost of establishment is needed. A previous report [7] indicated that by growing two plants per cell, growers could optimize yield of bulbs $>76 \mathrm{~mm}$ in diameter. Short-day onion grown with three seedlings per round cell on a 242-cell flat resulted in similar yields, and larger jumbo-size bulbs, than direct seeding at a reduced cost per plant [8].

Cultural practices such as plant arrangement and density can affect bulb size, shape and yield $[2,12]$. To obtain bulbs in the 50 to $70 \mathrm{~mm}$ diameter range, onion are generally grown at 50-100 plants $\mathrm{m}^{-2}$ [3]. In New Zealand, increased plant density from 50 to 130 plants $\mathrm{m}^{-2}$ increased the percentage of shape rejects as measured by the bulb shape index [6]. That study used the cv. Pukekohe Longkeeper, which is believed to be derived from the same Spanish origin as the 'Valenciana' populations [2]. The effect of the transplant establishment system with two or three plants per hill on the bulb shape index (ratio of bulb diameter and height) has not been reported. The objective of this study was to determine the growth components, yield and onion shape of transplanted long-day onion $\mathrm{cv}$. Valcatorce INTA in response to increased seedling density, with one, two or three seedlings per cell of $10 \mathrm{~cm}^{3}$ on a 228-cell flat.

\section{MATERIALS AND METHODS}

\subsection{Plant material and transplant growth}

The experiment used the long-day onion cv. Valcatorce INTA, a 'Valenciana' type. Valcatorce is a late-maturing cultivar requiring a 14-h photoperiod to produce bulbs [4]. It is globe-shaped with two to three dark brown outer scales, a bulb diameter of $7.3 \pm 2.3 \mathrm{~cm}$, and a bulb weight of $210 \pm 31.6 \mathrm{~g}$. It was developed from 'Valenciana' populations, which trace back from the Grano-type onions from the Valencia region of Spain [2]. Containerized seedlings were grown in polystyrene flats of 228 cells $\left(2.3 \mathrm{~cm}\right.$ side, $2.5 \mathrm{~cm}$ depth, and $10 \mathrm{~cm}^{3}$ volume). Seeds were planted with one, two or three seeds per cell in a greenhouse nursery (Plantar Inc., La Plata) located in the Province of Buenos Aires (Lat 34 $45^{\prime} \mathrm{S}$, Long $58^{\circ} 04^{\prime} \mathrm{W}$ ), Argentina. Bareroot (BR) seedlings were grown near to the field experiment in a low tunnel $0.8 \mathrm{~m}$ wide and covered by perforated polyethylene $(50 \mu$ thickness, $1.1 \mathrm{~cm}$ diameterholes which perforated $2.45 \%$ of the total area). Seeds were placed at a rate of $10 \mathrm{~g} \mathrm{~m}^{2}$ with a $10 \mathrm{~cm}$ between-row spacing and $1.5 \mathrm{~cm}$ depth. The soil type used for BR production was as described below in the field site section.

\subsection{Transplant treatments}

A summary of the treatments and planting characteristics are described in Table I. Treatments were one (TC1), two (TC2) or three (TC3) seedlings/cell, and single plants manually separated at transplanting from those grown with two (TC2-1) or three (TC3-1) seedlings/cell. Direct seeding (DS) and bareroot field-grown transplants (BR) were used as controls. Direct seeding was established with a vacuum seeder (Model SN-2-130, 1999, Agricola Italiana, 35010 Massanzago, Italy) on 8 August 2000 on four lines per bed with seeds spaced at $3.5 \mathrm{~cm}$. Transplants were established on 12 November 2000 on two lines per bed at $5-\mathrm{cm}$ spacing (BR, TC1, TC2-1 and TC3-1), $10 \mathrm{~cm}$ (TC2) and $15 \mathrm{~cm}$ (TC3). The initial plant population for $\mathrm{DS}$ and transplant treatments were 1632653 and $571429 \mathrm{pl} \mathrm{ha}^{-1}$, respectively.

\subsection{Field site and cultural conditions}

The field experiment was set up in Colonia La Merced, Provincia de Buenos Aires (Lat $38^{\circ} 40^{\prime} \mathrm{S}$, Long $62^{\circ} 30^{\prime} \mathrm{W}$ ),

Table I. Stand establishment treatments and planting characteristics of the experiment.

\begin{tabular}{|c|c|c|c|c|c|c|c|}
\hline Stand establishment & $\begin{array}{c}\text { Direct } \\
\text { seeding }\end{array}$ & $\begin{array}{l}\text { Bareroot } \\
\text { transplant }\end{array}$ & $\begin{array}{l}\text { One plant } \\
\text { per cell }\end{array}$ & $\begin{array}{c}\text { Two plants } \\
\text { per cell }\end{array}$ & $\begin{array}{c}\text { Three plants } \\
\text { per cell }\end{array}$ & $\begin{array}{c}\text { Single plant from } \\
\text { TC2 }\end{array}$ & $\begin{array}{c}\text { Single plant } \\
\text { from TC3 }\end{array}$ \\
\hline Nomenclature & $\mathrm{DS}$ & $\mathrm{BR}$ & $\mathrm{TC} 1$ & $\mathrm{TC} 2^{\mathrm{Z}}$ & $\mathrm{TC}^{\mathrm{z}}$ & TC2-1 & TC3-1 \\
\hline $\begin{array}{l}\text { Plant production } \\
\text { system }\end{array}$ & $\begin{array}{c}\text { Direct } \\
\text { seeding }\end{array}$ & $\begin{array}{l}\text { Low tunnel- } \\
\text { perforated } \\
\text { polyethylene }\end{array}$ & $\begin{array}{c}10 \mathrm{~cm}^{3} \\
\text { cell, 228- } \\
\text { cell/flat }\end{array}$ & $\begin{array}{c}10 \mathrm{~cm}^{3} \\
\text { cell, } 228- \\
\text { cell/flat }\end{array}$ & $\begin{array}{c}10 \mathrm{~cm}^{3} \\
\text { cell, } 228- \\
\text { cell/flat }\end{array}$ & $\begin{array}{c}10 \mathrm{~cm}^{3} \\
\text { cell, } 228- \\
\text { cell/flat }\end{array}$ & $\begin{array}{l}10 \mathrm{~cm}^{3} \\
\text { cell, } 228- \\
\text { cell/flat }\end{array}$ \\
\hline Seeding date & 8-Aug & 5-Aug & 1-Sep & 1-Sep & 1-Sep & 1-Sep & 1-Sep \\
\hline Emergence & 7-Sep & 23-Aug & 15-Sep & 15-Sep & 15-Sep & 15-Sep & 15-Sep \\
\hline Transplanted & - & 12-Nov & 12-Nov & 12-Nov & 12-Nov & 12-Nov & 12-Nov \\
\hline Lines/bed & 4 & 2 & 2 & 2 & 2 & 2 & 2 \\
\hline Plant spacing & $3.5 \mathrm{~cm}$ & $5.0 \mathrm{~cm}$ & $5.0 \mathrm{~cm}$ & $10.0 \mathrm{~cm}$ & $15.0 \mathrm{~cm}$ & $5.0 \mathrm{~cm}$ & $5.0 \mathrm{~cm}$ \\
\hline $\begin{array}{l}\text { Initial plant } \\
\text { density }\left(\mathrm{pl} \mathrm{ha}{ }^{-1}\right)\end{array}$ & 1632653 & 571429 & 571429 & 571429 & 571429 & 571429 & 571429 \\
\hline $\begin{array}{l}\text { Harvest } \\
\text { DAE or DAT }\end{array}$ & $\begin{array}{l}\text { 11-Mar } \\
185 \text { DAE }\end{array}$ & $\begin{array}{l}\text { 11-Mar } \\
119 \text { DAT }\end{array}$ & $\begin{array}{l}\text { 11-Mar } \\
\text { 119 DAT }\end{array}$ & $\begin{array}{l}\text { 11-Mar } \\
119 \text { DAT }\end{array}$ & $\begin{array}{l}\text { 11-Mar } \\
119 \mathrm{DAT}\end{array}$ & $\begin{array}{l}\text { 11-Mar } \\
119 \text { DAT }\end{array}$ & $\begin{array}{l}\text { 11-Mar } \\
\text { 119 DAT }\end{array}$ \\
\hline
\end{tabular}

${ }^{\mathrm{z}} \mathrm{TC} 2$ and TC3 were established without plant separation.

$\mathrm{DAS}=$ days after seeding; DAE = days after emergence; DAT = days after transplanting. 


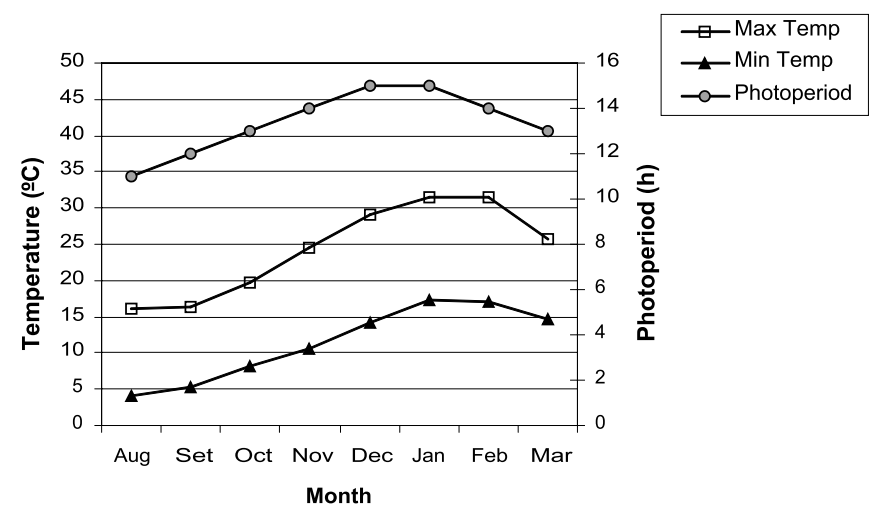

Figure 1. Minimum and maximum temperatures, and photoperiod at Bahia Blanca, Pcia. Buenos Aires (Lat $38^{\circ} 42^{\prime}$ S, Lon $62^{\circ} 28^{\prime} \mathrm{W}$ ), Argentina.

Argentina. The soil type was Haplustol Fluvéntico, with organic matter of $8.52 \%$; pH 8.2; available $\mathrm{P}, 23.4 \mathrm{ppm}$, and electrical conductivity (EC) $2.05 \mathrm{dS} \mathrm{m}^{-1}$. Transplants grown in flats were hardened by exposing them to outdoor conditions for three days before planting. Plants were established on nonfumigated $12-\mathrm{m}$ single raised beds on $0.70 \mathrm{~m}$ centers on 12 November 2000 . Weed control in the DS treatment was done with linuron $\left(350 \mathrm{~g}\right.$ a.i. $\left.\mathrm{ha}^{-1}\right)$, a pre-emergence herbicide, plus fluroxipir (140 g a.i. ha $\left.{ }^{-1}\right)$, and three post-emergence applications of cletodim $\left(144 \mathrm{~g}\right.$ a.i. $\left.\mathrm{ha}^{-1}\right)$ applied on 1 and 16 October, and 6 November. Due to the residual high soil fertility obtained from the previous alfalfa (Medicago sativa L.) crop, $\mathrm{N}$ was the only nutrient applied (urea source) at a rate of $45 \mathrm{~kg}$ $\mathrm{N}$ ha $^{-1}$ on 12 December 2000 . Mean minimum temperatures during planting were $5{ }^{\circ} \mathrm{C}$ and $10{ }^{\circ} \mathrm{C}$ for direct seeding and transplants, respectively (Fig. 1), while mean maximum temperatures were about $32{ }^{\circ} \mathrm{C}$ during January and February. The photoperiod increased constantly from 11 to $15 \mathrm{~h}$ during August to December, respectively (Fig. 1). Rainfall accumulated to $262 \mathrm{~mm}$ during the cropping season, and siphon irrigation from canals was applied 23 times throughout the growth cycle. Irrigation water had a $\mathrm{pH}$ of 8.5 and $\mathrm{EC} 0.9 \mathrm{dS} \mathrm{m}^{-1}$. The concentrations of anions and cations of the irrigation water (meq $1^{-1}$ ) were: chlorides, 2.8; bicarbonate, 2.5; sulfates, 3.5; sodium, 0.9; potassium, 6.0; calcium+ magnesium, 1.7; total anions, 8.8; total cations, 8.6; and sodium absorption ratio, 1.

\subsection{Plant sampling}

Plants were sampled throughout development at weekly or bi-weekly intervals from mid-November to February. Growth variables included plant height, root number, bulb diameter, leaf number, and dry weights of roots and shoots. A total of four plants per replication were carefully removed from the soil. Roots and leaves were counted immediately and dry weights of roots, bulb and leaves were determined after placing samples in an oven at $60{ }^{\circ} \mathrm{C}$ for 7 days. Plants were harvested from 6-m-long plots when an average of $80 \%$ of the pseudostems bent over on 11 March 2000. At harvest, bulbs were sorted by diameter into four commercial size classes: small $(35-50 \mathrm{~mm})$, medium $(50-60 \mathrm{~mm})$, large $(60-70 \mathrm{~mm})$

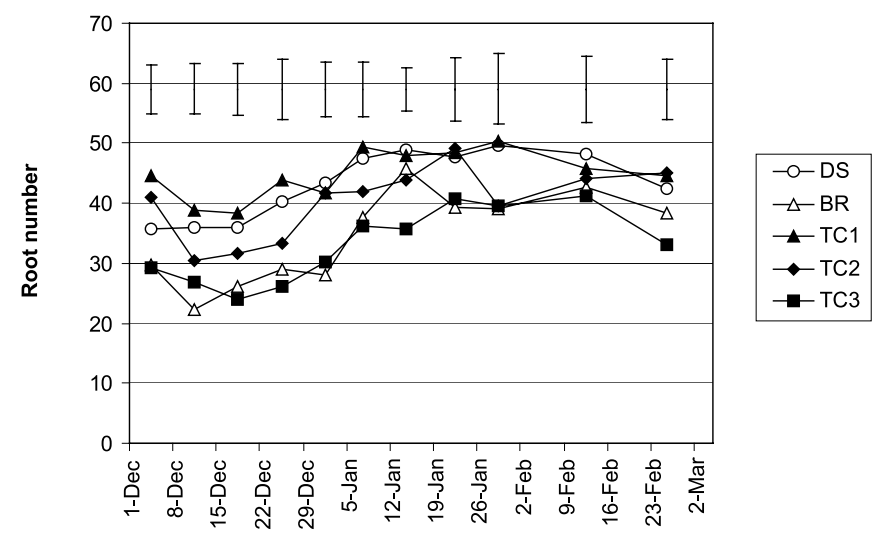

Figure 2. Root number of onion cv. Valcatorce INTA in response to stand establishment methods. Direct seeding (DS), field-grown bareroot transplants (BR), and containerized transplants (TC1, TC2, and TC $3=$ one, two, and three plants per cell of $10 \mathrm{~cm}^{3}$ on $228 \mathrm{cell} /$ flat). Each bar represents LSD at $5 \%$.

and jumbo (>70 mm). During bulb sorting, samples of six bulbs per replication were taken from each class size, and individually measured for diameter and height to estimate the bulb shape index. This index was calculated by the ratio of diameter to height to determine whether onions were flat (index $>1$ ), globe (index $=1$ ) or torpedo (index $<1$ ).

\subsection{Statistics}

The experiment was conducted using a randomized complete block design with four replications. Each experimental unit consisted of four rows of $6 \mathrm{~m}$ length with a total area of $16.8 \mathrm{~m}^{2}$. Shoot and root growth, bulb quality and yield size class data were subjected to analysis of variance (ANOVA) and means separated by LSD $(P<0.05)$. When the relationship of the bulb index and bulb diameter was linear, the homogeneity of the variances and the regression slopes were compared at $P \leq 0.05$ by the $t$ test [11].

\section{RESULTS AND DISCUSSION}

\subsection{Transplant growth}

Throughout most of the plant development, root number was significantly higher for TC1 compared with BR and TC3 (Fig. 2). Root number for DS increased uniformly (from 35 up to 50 roots per plant) from 1 December until 29 January. Less differences between treatments were measured during mid- to late development (Fig. 2). Root dry weight followed the same trend as root number (not shown). Leskovar and Vavrina (1999) compared root growth of transplanted onion cv. Texas Grano $1015 \mathrm{Y}$ in response to cell volume and age. They found that root number and root dry wt. increased linearly in response to transplant age (6 to 12 weeks old), but were not affected when plants grown in $7.1 \mathrm{~cm}^{3}$ cell volume were compared with those grown in $4.0 \mathrm{~cm}^{3}$ cells [9]. 


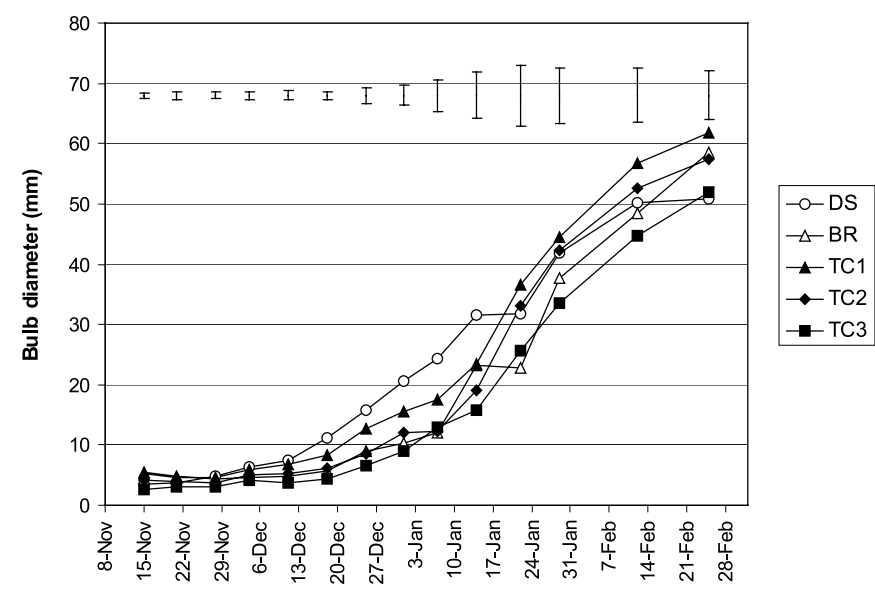

Figure 3. Bulb diameter of onion cv. Valcatorce INTA in response to stand establishment methods. Direct seeding (DS), field-grown bareroot transplants (BR), and containerized transplants (TC1, TC2, and TC3 $=$ one, two, and three plants per cell of $10 \mathrm{~cm}^{3}$ on 228 cell/ flat). Each bar represents LSD at 5\%.

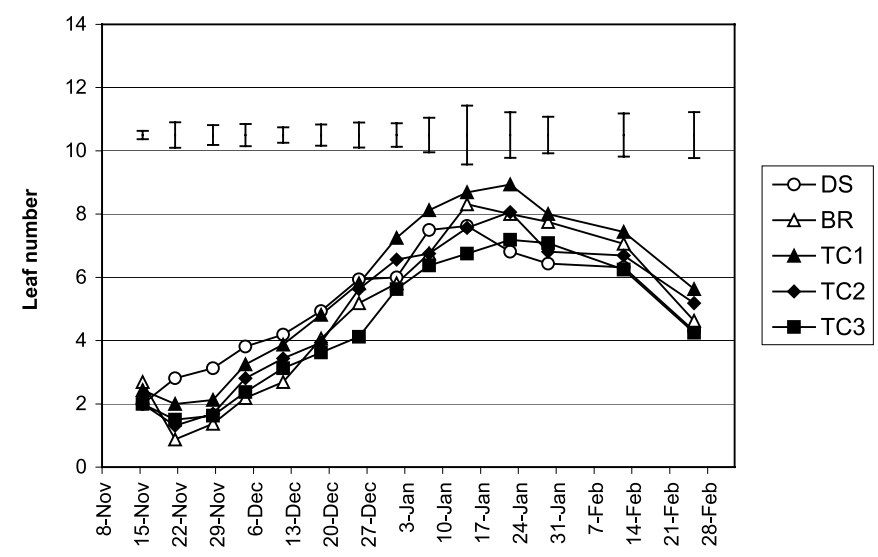

Figure 4. Leaf number of onion cv. Valcatorce INTA in response to stand establishment methods. Direct seeding (DS), field-grown bareroot transplants (BR), and containerized transplants (TC1, TC2, and TC $3=$ one, two, and three plants per cell of $10 \mathrm{~cm}^{3}$ on 228 cell/ flat). Each bar represents LSD at $5 \%$.

Bulbing for all treatments started around 11 December, 95 days after emergence for DS, or 60 days after transplanting (Fig. 3). Stimulus for bulbing and the subsequent rate of bulbing increases with photoperiod [2]. Bulbing occurred when the photoperiod was longer than 13.5 hours (Fig. 1). Initially, DS had a rapid and higher bulbing rate than TC treatments, while most transplants exhibited a higher bulbing rate after 7 January or 87 DAT (Fig. 3). Before final maturity, bulb size for TC1 was significantly higher than DS and TC3, but not compared with BR and TC2. Comparing transplants produced with either two or three plants per cell, bulb size for TC2 was not significantly different than TC3 (Fig. 3), and similar to TC2-1 and TC3-1 when measured on 25 February, two weeks before harvesting (not shown).

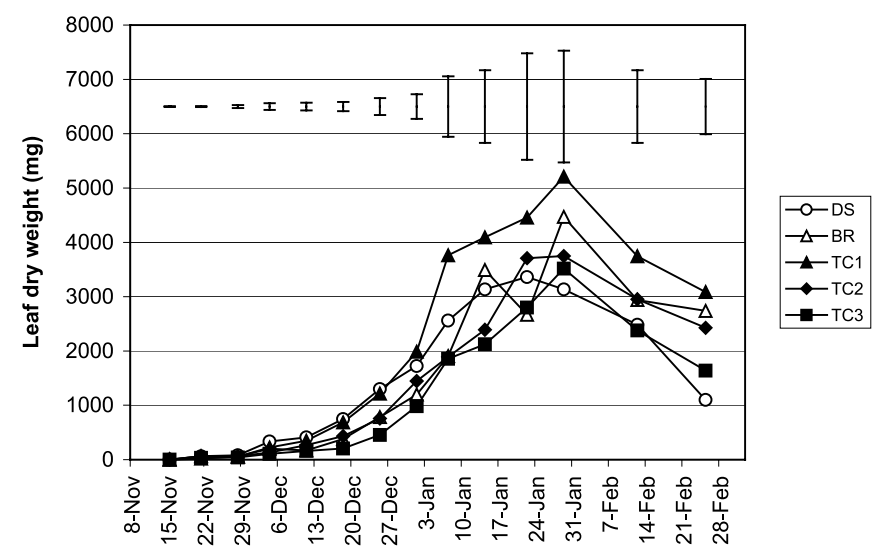

Figure 5. Leaf dry weight of onion cv. Valcatorce INTA in response to stand establishment methods. Direct seeding (DS), field-grown bareroot transplants (BR), and containerized transplants (TC1, TC2, and TC3 $=$ one, two, and three plants per cell of $10 \mathrm{~cm}^{3}$ on $228 \mathrm{cell} /$ flat). Each bar represents LSD at 5\%.

Leaf number was higher for DS during early development, and ranged from 2 to 4 leaves between 15 November and 11 December (Fig. 4). Thereafter (between 27 December and 24 January), leaf number was higher for TC1 as compared with TC3 (Fig. 4), TC2-1 or TC3-1 (not shown). Leaf mass per plant increased at a low rate for all establishment treatments between 15 November and 11 December, thereafter, leaf mass was greatest for TC1, and near maturity (25 February) leaf mass for TC1 was significantly higher than DS and TC 3 , but similar to BR and TC2 (Fig. 5). Leaf size, age, and the duration of leaf growth are major factors that influence the size and yield of onions. They are implicated in processes that include light interception and absorption, photosynthesis capacity, and conversion of photosynthates to transportable sucrose to bulbs [2]. The decrease in leaf mass for DS and TC3 may be a consequence of earlier bulb development, which has a direct effect on preventing renewal or maintenance of canopy growth. Conversely, the higher leaf mass for TC1, BR and TC2 (Fig. 5) and TC2-1 and TC3-1 (not shown) may increase the potential to achieve high yields.

\subsection{Yield and quality}

Bulb size class yield differed significantly in response to stand establishment systems (Tab. II). Higher yields for the small class size (35-50 $\mathrm{mm}$ diameter) were measured for DS and TC3 (three plants per cell planted without separation). The latter also had the highest amount of bulbs in the next size category (50-60 mm). Conversely, TC1, TC2, TC2-1, TC3-1 and BR had significantly higher yields than DS in the 60-70 mm category. The most valuable size for export markets in South America (e.g. Brazil) is 50-70 mm diameter. Overall, for bulb sizes in the 50-70 mm diameter category, yields were best from transplants TC2 and TC3, 36\% and 31\% higher than the direct seeded control, respectively. TC1 transplants produced $36 \%$ of the total marketable onions in the jumbo size category (>70 mm diameter), compared with $24 \%$ and $16 \%$ for BR and DS, respectively. 
Table II. Total marketable yield by size class (diameter in $\mathrm{mm}$ ) and bulb index (diameter/height ratio) of small onions (35-50 mm) of long-day onion cv. Valcatorce INTA in response to increased seedling density.

\begin{tabular}{|c|c|c|c|c|c|c|}
\hline \multirow[b]{2}{*}{ Establishment } & \multicolumn{5}{|c|}{ Total and size class onion yield $\left(\mathrm{t} \mathrm{ha}^{-1}\right)$} & \multirow[b]{2}{*}{ Diameter/height ratio } \\
\hline & Total & $\begin{array}{c}\text { Small } \\
(35-50 \mathrm{~mm})\end{array}$ & $\begin{array}{l}\text { Medium } \\
(50-60 \mathrm{~mm})\end{array}$ & $\begin{array}{c}\text { Large } \\
(60-70 \mathrm{~mm})\end{array}$ & $\begin{array}{c}\text { Jumbo } \\
(>70 \mathrm{~mm})\end{array}$ & \\
\hline DS & 57.2 & $11.8 \mathrm{a}$ & $22.2 \mathrm{ab}$ & $13.8 \mathrm{~b}$ & $9.4 \mathrm{~b}$ & $0.87 \mathrm{~b}$ \\
\hline $\mathrm{BR}$ & 58.0 & $4.4 \mathrm{ab}$ & $15.8 \mathrm{~b}$ & $24.0 \mathrm{a}$ & $13.7 \mathrm{~b}$ & $0.86 \mathrm{~b}$ \\
\hline $\mathrm{TC} 1$ & 68.8 & $2.6 \mathrm{~b}$ & $14.6 \mathrm{~b}$ & $27.0 \mathrm{a}$ & $24.8 \mathrm{a}$ & $0.89 \mathrm{~b}$ \\
\hline $\mathrm{TC} 2$ & 67.3 & $6.8 \mathrm{ab}$ & $23.2 \mathrm{ab}$ & $25.9 \mathrm{a}$ & $11.4 \mathrm{~b}$ & $0.82 \mathrm{~b}$ \\
\hline $\mathrm{TC} 3$ & 64.7 & $11.4 \mathrm{a}$ & $27.1 \mathrm{a}$ & $20.1 \mathrm{ab}$ & $6.2 \mathrm{~b}$ & $0.88 \mathrm{~b}$ \\
\hline TC2-1 & 57.7 & $3.2 \mathrm{~b}$ & $14.1 \mathrm{~b}$ & $24.2 \mathrm{a}$ & $16.4 \mathrm{~b}$ & $1.01 \mathrm{a}$ \\
\hline TC3-1 & 54.0 & $5.8 \mathrm{ab}$ & $18.3 \mathrm{ab}$ & $22.6 \mathrm{a}$ & $7.2 \mathrm{~b}$ & $0.87 \mathrm{~b}$ \\
\hline
\end{tabular}
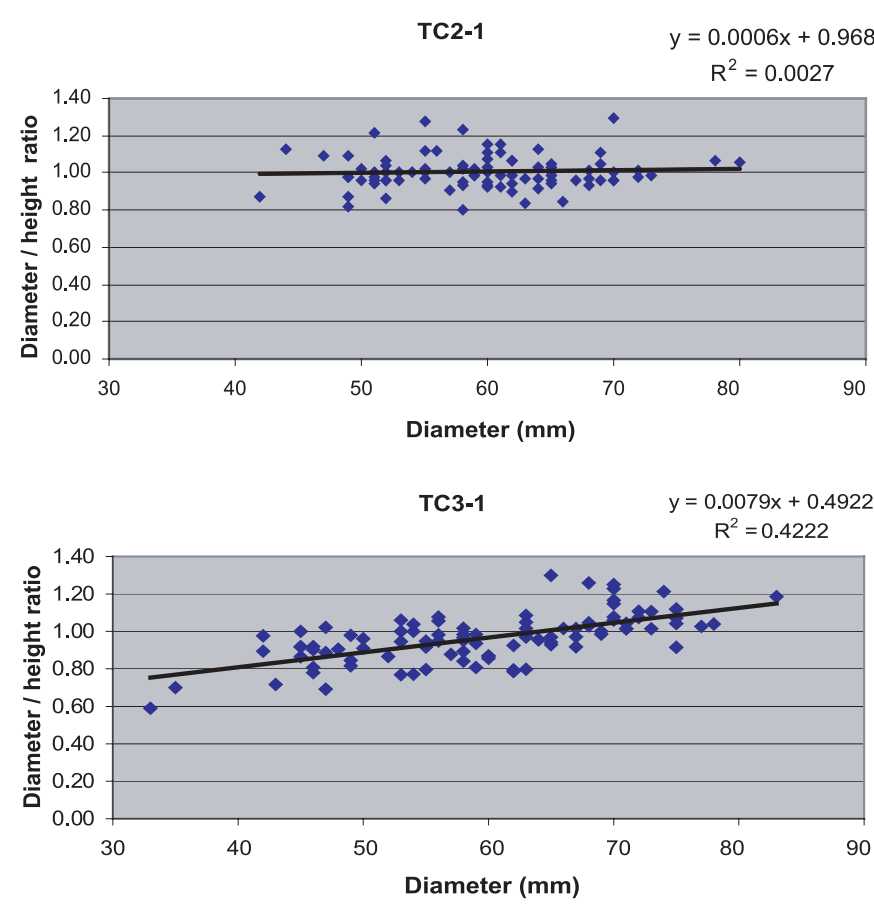

Figure 6. Relationships between bulb index (diameter/height) and bulb diameter obtained from random onion samples from containerized transplants. Treatments shown are single plants manually separated at transplanting from those grown with two (TC2-1) or three (TC3-1) seedlings per cell.

The preferred size for short-day onions in U.S. markets is colossal (> $102 \mathrm{~mm})$. An earlier study reported that one plant/ cell had a higher percentage of bulbs $>102 \mathrm{~mm}$, compared with two or three plants per cell [7]. Another transplant study, comparing cell volumes, reported that plants produced in $4 \mathrm{~cm}^{3}$ volume had a $16 \%$ decrease in jumbo onions compared with $7.1 \mathrm{~cm}^{3}$ volume [9]. In our study, increasing seedling density to two (TC2) or three (TC3) plants per $10 \mathrm{~cm}^{3}$ volume, equivalent to $5 \mathrm{~cm}^{3}$ or $3.3 \mathrm{~cm}^{3}$ volume per plant, respectively, also decreased yield of bulbs larger than $70 \mathrm{~mm}$ diameter.
Total yields increase with plant density, which has been associated with an increase in light interception by the leaf canopy [2]. However, increasing plant density, either when established by direct seeding or containerized transplants, decreased individual bulb size $[10,12]$. In our study all transplants were established at the same initial plant populations, and total yields were not statistically different between the TC treatments.

\subsection{Bulb shape}

Bulb shape had a tendency towards a flat shape (diameter/ height ratio greater than 1) for onions greater than $60 \mathrm{~mm}$ in diameter (not shown), and towards a semi-torpedo or elongated shape (diameter/height ratio less than 1) for the smaller class in DS, BR, TC1, TC2, TC3 and TC3-1, except for the TC2-1 (Tab. II). Herison et al. (1993) reported that seedling density affected bulb shape (or index), being 1.12, 0.95 and 0.87 for one, two or three plants per cell. Regardless of grading, most onions obtained from TC2-1 were in the globe shape (diameter/height ratio $=1$ ), a response that differed from TC3-1 (Fig. 6) and the other treatments. The slope $\left(b_{2}\right)$ for TC3-1 was significantly higher $\left(b_{2}=0.0079\right)$ than the slope $\left(b_{1}\right)$ for TC2-1 $\left(b_{1}=0.0006\right)$. It is unknown whether this morphological response is related to either root competition and interaction of neighboring plants during the initial growth in the $10 \mathrm{~cm}^{3}$ cell volume or subsequent development in the field.

\section{CONCLUSION}

Containerized transplants grown with two plants per cell may be an alternative and cost-effective system that can increase yield of high value marketable bulbs over the traditional direct seeding system. Planting two plants per hill in the field at wider spacings (TC2) allows the bulb to grow into available spacing, particularly in light soils. In addition, planting at wider spacings may speed up the transplanting operation at a reduced cost compared with narrow planting spacings required for single plants (TC1). Another advantage of cell-grown 
transplants is that they significantly decrease the growing period in the field as compared with direct seeding, thus reducing the potential for environmental and biological risks affecting stand establishment, development and maturity.

Acknowledgments: Financial support for this research was provided by the UNS project 24/A089. The authors thank Mr. Miguel Farina and PLANTAR Inc. for their collaboration and support of this experiment.

\section{REFERENCES}

[1] Ayastuy M.E., Luayza G.G., Orioli G., Consideraciones sobre el manejo de la fertilizacion en cultivo de cebolla en el Valle Bonaerense del Río Colorado, 1997, Boletín Técnico No. 6, E.E.A. H. Ascasubi INTA, $11 \mathrm{p}$.

[2] Brewster J.L., Onions and other vegetable alliums, CAB Intl., UK (1994)

[3] Frappell B.D., Plant spacing of onions, J. Hortic. Sci. 48 (1973) 19-28.

[4] Galmarini C., Onion cultivars released by La Consulta Experimental Station, INTA, Argentina, Hortscience 35 (2000) 1360-1362.
[5] Galmarini C.R., Della Gaspera P.G., Efecto de la época de transplante y la densidad de plantación en el cultivo de cebolla tipo valencianita, Hort. Arg. 14 (1995) 23-29.

[6] Grant D.G., Carter B.V., The influence of cultural factors on the bulb shape of the onion (Allium cepa L.) cultivar 'Pukekohe Longkeeper', Acta Hortic. 433 (1997) 527-532.

[7] Herison C., Masabni J.G., Zandstra B.H., Increasing seedling density, age, and nitrogen fertilization increases onion yield, HortScience 28 (1993) 23-25.

[8] Leskovar D.I., Kolenda K., Pena J., Containerized onion transplants: III. Yield response to increased seedling density, UREC-016 (2002).

[9] Leskovar D.I., Vavrina C.S., Onion growth and yield are influenced by transplant tray cell size and age, Sci. Hortic. 80 (1999) 133-143.

[10] McGeary D.J., The effect of plant density on shape, size, uniformity, soluble solids content, and yield of onions suitable for pickling, J. Hortic. Sci. (1985) 83-87.

[11] Snedecor G.W., Cochran W.G, Statistical methods, Iowa State Univ. Press. Ames. (1967).

[12] Stoffella P.J., Planting arrangement and density of transplants influence sweet spanish onion yield and bulb size, HortScience 31 (1996) 1129-1130. 